\title{
Türk Bankacılık Endüstrisinde Performansın Belirleyenleri ve Politik İstikrarsızlık İlişkisi
}

\author{
Ayşe Elif AY YALÇINKAYA, Department of Economics, Faculty of Economics and Administrative Sciences, \\ Dokuz Eylul University, Turkey; e-mail: elif.ay@deu.edu.tr
}

Selim ŞANLISOY, Department of Economics, Faculty of Economics and Administrative Sciences, Dokuz Eylul University, Turkey; e-mail: selim.sanlisoy@deu.edu.tr

$\ddot{U}$ zeyir AYDIN, Department of Economics, Faculty of Economics and Administrative Sciences, Dokuz Eylul University, Turkey; e-mail: uzeyir.aydin@deu.edu.tr

\section{The Determinants of Performance in Turkish Banking Industry and Political Instability}

\begin{abstract}
In this study, it is aimed to determine the effects of political instability on the performance of Turkish banking industry within the internal and external variables for the period of 2002-2015. Return on assets is used as a criteria for performance of banking industry in terms of panel data analysis. In the context of the results, the banks' performance is affected in a negative way by political instability, the banks' failure for economies of scale, increasing interest rate for borrowing and volatility of foreign exchange. The performance is affected in a positive way by increasing capital adequacy ratio, growth of revenue and increasing credit volume and scale of the banks. Thus, the banks should consider national and global economic and political developments along with their own balance sheet items.

Keywords $\quad$ : Bank Performance, Political Instability, Panel Data Analysis, Profitability Determinants.

JEL Classification Codes : $\quad$ C33, D22, G21.

$\ddot{\mathbf{O z}}$

$\mathrm{Bu}$ çalışma 2002-2015 yılları arasında çeyreklik verilerle Türkiye'de sıklıkla yaşanan politik istikrarsızlığın içsel ve dişsal değişkenlerle birlikte Türk bankacılık endüstrisinin performansı üzerindeki etkilerini ortaya koymayı amaçlamıştır. Panel veri analizi yönteminin uygulandığı çalışmada, bankacılık endüstrisinin performans ölçütü olarak aktif karlılığı kullanılmıştır. Analiz sonuçlarına göre; politik istikrarsılık, bankaların ölçek ekonomisinden uzaklaşması, borç verme faiz oranındaki yükselme ve döviz kurlarındaki oynaklık artışı bankaların performansını negatif yönde etkilemektedir. Diğer yandan, sermaye yeterlilik rasyosunun yükselmesi, hâsıla artışı ve bankaların kredi hacimlerini ve ölçeklerini büyütmesi; performansa pozitif katkı yapmaktadır. Buna göre, bankaların kendi bilanço kalemlerini izlemelerinin yanı sıra ulusal ve küresel düzeyde ekonomik ve politik gelişmeleri dikkate almaları gerekmektedir.
\end{abstract}


Anahtar Sözcükler
: $\quad$ Banka Performansı, Politik İstikrarsızlık, Panel Veri Analizi, Karlılık

Belirleyenleri.

\section{Giriş}

Piyasa sisteminin daha kurumsal olarak işletilmeye başladığı 1980'li yıllarla birlikte, serbestliğin sağlandığı özellikle finansal kesimde önemli oranlarda büyüme kaydedilmiştir. Finansal kesimin en önemli parçası olan bankacılıkta 1980'lerden 2000'lere kadar olan dönemde, sabit fiyatlarla toplam aktifler yaklaşık yüzde 400, toplam krediler yaklaşık yüzde 200 ve toplam mevduat yaklaşık yüzde 660 artış gösterirken, GSMH'daki artış oranı sadece yüzde 85 düzeyinde kalmıştır. Bu dönemde, yüksek enflasyon ve buna bağlı ekonomik belirsizlik -öngörülemezlik- devam etmekle birlikte; yurtdışından kaynak temini imkânının artması, mevduat faizlerinin serbest bırakılması, döviz cinsinden tasarruf yapabilme imkânlarının genişletilmesi sonucu finansal sistemin büyümesi hızlanmıştır. Mevduat en hızlı artış gösteren kalem olmuş, kredi stokunun büyümesi ise kamu kesiminin kaynak ihtiyacı nedeniyle özellikle 1990'lı yıllar boyunca devlet iç borçlanma senetlerine yönelen talep nedeniyle sınırlı kalmıştır (Türkiye Bankalar Birliği, 2008). 1980'li ve 1990'lı yıllarda finansal kesim ağırlıklı bu büyüme eğilimi yapısallaşmış olup, 2000'li yıllarda sürmüştür.

2000'li yılların başında enflasyon belirsizliğini ortadan kaldırma amaçlı ve Uluslararası Para Fonu destekli bir politika izlenmiştir. Bu politika belli ölçüde öngörülebilirlik ve sürdürülebilirlik sağlamışken, döviz kurları üzerinde çıkan baskıyla ödemeler bilançosu bağlamında reel ve finansal dengesizlikler ortaya çıkmıştır. Bu dengesizliklerin aşılması için uygulanan, piyasalaştırma ve özelleştirme ağırlıklı ekonomi politikası, küresel piyasalardaki likidite arzının yüksekliği paralelinde, ekonomik büyümeye ivme kazandırmıştır. Küresel finansal sermaye akışları, banka kredileri, menkul ve gayrimenkul değerlere yatırım, tüketim gibi alanlardaki yükseliş ekonomik büyümenin temelini oluşturmuştur.

2008'den beri içinde bulunulan küresel krizin özellikle finansal alandaki aşırı talep artışından kaynaklanması üzerine tartışmalar ve politika önerileri sürmektedir. Ne var ki, çözüm yolunun yine finansal kesim üzerinden kurgulanması eleştirilmektedir. 2000'li yıllarda finansal kesimin büyüme eğilimi kriz nedeniyle zayıflasa da, finansal kesim yönlendirmeli ekonomik yapı sürmektedir: 2002 yılı son çeyreğinde bankaların ticari kredilerindeki faiz oranı yüzde 41,3 ve tüketici kredilerindeki faiz oranı yüzde 42,6 iken, 2015 yılının ikinci çeyreğinde ticari kredilerde yüzde 11,8 ve tüketici kredilerinde yüzde 14,4'lük faiz oranları söz konusu olmuştur. Bu dönemde ticari krediler ve tüketici kredileri artış eğilimi göstermiştir. Bu durum, özellikle gayrimenkul yatırımları ve tüketim açısından bankaların kârlılık kaynaklarının güçlü ve sürdürülebilir olduğu anlamına gelmektedir.

Kredi faiz oranlarındaki düşüş ile kredi hacimlerindeki artışın finansal kesimin büyüme yolunu işaret etmesinin yanında, bir başka gösterge sermaye yeterlilik oranıdır. 2002'nin son çeyreğinde bankaların sermaye yeterlilik oranı yüzde 24,2 iken, 2015'in ikinci 
Ay Yalçınkaya, A.E. \& S. Şanlısoy \& Ü. Aydın (2016), “Türk Bankacılık Endüstrisinde

Performansın Belirleyenleri ve Politik İstikrarsızlık İlişkisi”, Sosyoekonomi, Vol. 24(27), 161-182.

çeyreğinde yüzde 15,4 olarak gerçekleşmiştir. Bu oranın düşüş eğilimi göze çarpmakla birlikte, kabul edilebilir olan yüzde 8 'in üzerinde olması, bankaların finansal yapısının yerinde olduğunu göstermektedir. 2015'in ilk yarısında bireysel kredilerdeki düşüş eğilimi durmuş, kurumsal krediler ise artmaya devam etmiştir. Krediler doğrultusunda 2014 yılında nominal olarak azalan kâr hacmi, 2015 yılının ilk yarısında 2014 yılının ilk yarısına göre yüzde 11 oranında bir artış göstermiştir (Türkiye Bankalar Birliği, 2015).

1990'lı yıllardan itibaren gelişmiş ülkelerle gelişmekte olan ülkeler arasındaki gelişmişlik farklılığının kaynakları araştırılırken dikkatler giderek politik ve kurumsal faktörler üzerinde yoğunlaşmaya başlamıştır. Politik değişkenlerin ülkeler arasındaki gelişmişlik farklılıkları üzerindeki etkisini araştırmaya yönelik çalışmalarda ilk ele alınan değişken politik rejim tipi olmuştur. Bir anlamda gelişmişlik farklılığının açıklanmasında demokrasinin bir değişken ya da ölçüt olarak kullanılmasının en önemli nedeni ekonomik gelişmede güçlü kurumların etkili olması ve güçlü kurumlarında demokrasi ile özdeş olarak görülmesidir. Genellikle gelişmiş ülkelerde demokratik rejimlerin bulunması, gelişmekte olan ülkelerde ise demokrasi dışı rejimlerin varlığı ya da demokrasinin yeterince kurumsallaşmamış olması politik rejim tipi farklılıklarının gelişmişlik farklılıklarını açıklayan en önemli değişken olarak görülmesini beraberinde getirmiştir. Bununla birlikte literatür incelendiğinde politik rejim tipi ile ekonomik performans arasındaki ilişki konusunda kesin bir yargıya ulaşılamamıştır. Bu durum ekonomik değişkenler üzerinde etkili olabilecek başka politik değişken arayışlarını ortaya çıkarmıştır. Bu arayışların bir sonucu olarak da politik istikrarsızlık değişkeni literatürde kullanılmaya başlanmıştır. Dolayısıyla mevcut politik rejim tipinden çok, söz konusu rejim tipinin istikrarı ön plana çıkmıştır. Zira politik istikrar demokratik yönetimlerde sağlanabileceği gibi otokratik yönetimlerde de sağlanabilir. Dolayısıyla politik istikrarsızlık da her iki rejim tipinde de ortaya çıkabilir.

Ekonomik birimler sadece mevcut duruma göre ekonomik kararlarını almamakta, gelecekteki koşulları ve beklentilerini de hesaba katmaktadırlar. Dolayısıyla ekonomik gelişme sürecinin devamlılığı girişimcilerin geleceği görebilme ufuklarının mümkün olduğunca uzun vadeli olmasına ve öngörülerinin gerçekleşme olasılıklarının yüksekliğine bağlıdır. Bunu belirleyen temel faktörlerden biri ekonomik faaliyeti belirleyen ve kurumsal çerçeveyi oluşturan politik değişkenlerdeki istikrardır. Bir ekonomide politik istikrarın varlığı girişimcilerin geleceği tahmin edebilme yeteneklerinin gelişmesine dolayısıyla da girişimcilerin daha uzun vadeli ve kalıcı ekonomik faaliyetlere yönelmesini sağlamaktadır. $\mathrm{Bu}$ durumda ekonomik istikrarın devamlılığı politik istikrara bağlı olarak ortaya çıkmaktadır. Bu noktadan hareketle politik istikrarsızlık tüm ekonomiyi dolayısıyla da bankacılık sektörünü de yakından ilgilendirmektedir. Aralarındaki ilişkiye geçmeden önce politik istikrarsızlık kavramına değinmek yerinde olacaktır.

Politik istikrarsızlık kavramına ilişkin üzerinde bir görüş birliğine varılmış bir tanımlama yoktur. Belki de bunun en önemli nedeni politik istikrarsızlığın farklı ülkelerde farklı kaynaklardan beslenmesi gösterilebilir. Bununla beraber politik istikrarsızlık olgusunda iki önemli nokta dikkati çekmektedir. 
İlkinde, mevcut anayasal sistemi değiştirmeye zorlama, ikincisinde ise anayasal düzen içinde olmakla birlikte, politik kutuplaşma, koalisyon hükümetleri, hükümetlerin değişim hızının yüksekliği gibi noktalar öne çıkmaktadır. Politik istikrarsızlık konusundaki temel çalışmalardan biri Alesina ve Perotti'ye (1996) aittir. Çalışmada politik istikrarsızlık:

- Hükümet değişiklikleri (anayasal veya değil),

- Sosyal huzursuzluk ve politik şiddet başlıklarında toplanmıştır.

Araştırmacılar politik istikrarsızlıktan daha çok ikinci maddeyi kastetmişlerdir. Çalışmada politik şiddetin ve sosyal huzursuzluğun dolayısıyla politik istikrarsızlığın nedeni gelir eşitsizliği olarak görülmüştür. Demokratik rejim tiplerinde ise politik istikrarsızlık göstergeleri daha çok şu başlıklarda toplanmaktadır: (Eren \& Bildirici, 2001: 31)

- Parlamentonun kutuplaşması,

- Koalisyon hükümetleri,

- Seçmenlerin kararsızlığı,

- Seçimlerin idaresi ve zamanlaması,

- Hükümet değiş̧ikliklerinin sıklığı.

Politik istikrarsızlık ülkedeki politik belirsizlikleri artırmakta bu da politik riski yükseltmektedir. Bu durum gerek finansal gerekse reel ekonomik değişkenler üzerinde etkili olarak ülke ekonomilerini etkilemektedir. Bu bağlamda da bankacıllk sektörü de bir yandan arz bir yandan da talep cephesinden etkilere maruz kalmaktadır. Çünkü riskin artması faiz oranlarını artırmakta bu ise bankaların maliyetlerini artırmakta, öte yandan faiz oranlarının yükselmesi kredi maliyetlerini artırmakta ve ekonomik birimlerin kredi taleplerini düşürmektedir. Öte yandan özellikle Türkiye gibi özel sektörünün öz sermaye yapıları çok güçlü olmayan ülkelerde firmalar normal dönemlerde yatırımlarının finansmanı için kredi kullanırken, kriz dönemlerinde nakit akış dengelerini koruyabilmek için ya da sağlayabilmek için kredi kullanmayı tercih etmektedirler.

Türkiye politik istikrasızlığın sıklıkla yaşandığı bir ülke olarak kabul edilebilir. İncelenen dönem açısından Türkiye'de politik istikrasızlığın kaynakları aşağıdaki gibi siralanabilir:

- 27 Nisan 2007 e-muhtırası ve potansiyel askeri müdahale endişesi,

- Gezi Parkı olayları,

- Merkez Bankası'nın bağımsızlığı ve Başkanlık Sistemi tartışmaları,

- Seçmenlerin kutuplaşması, 
Ay Yalçınkaya, A.E. \& S. Şanlısoy \& Ü. Aydın (2016), "Türk Bankacılık Endüstrisinde

Performansın Belirleyenleri ve Politik İstikrarsızlık İlişkisi”, Sosyoekonomi, Vol. 24(27), 161-182.

- Haziran 2015 seçimleri sonrasında kalıcı bir hükümetin kurulamaması ve buna bağlı olarak Kasım 2015'te erken seçim yapılması,

- Dönem içerisinde özellikle PKK terör örgütünün faaliyetleri olmak üzere yaşanan terör olayları,

- Politik istikrarsızlık aslında sadece ülke içerisinden kaynaklanmamaktadır. Aynı zamanda özellikle komşu ülkelerle olmak üzere diğer ülkelerle bağlantılı olmak üzere de ortaya çıkabilmektedir. Bu bağlamda, Türkiye'nin komşuları ile yaşadığı sorunlar ve içinde bulunulan coğrafyanın sürekli sorunlar üretmesi de politik istikrarsılılı̆ın önemli kaynaklarından birini oluşturmaktadır. Bu manada Irak ve Suriye'de yaşanan karışıklıklar, IŞID terörü, Rusya ile yaşanan sorunlar ve son dönemlerdeki önemli dış kaynaklı politik istikrarsızlık kaynaklarını oluşturmaktadır.

Politik istikrarsızlık, politik belirsizlik ve risk yaratarak ekonomik birimlerin gelecek ufkunu sınırlayarak beklentileri üzerinden ülke ekonomileri üzerinde etkili olmaktadır. Dolayısıyla politik istikrar ya da istikrarsızlık ile ekonomik değişkenler arasındaki ilişki kendisini gerek makro, gerek mezo ve gerekse mikro ekonomik alanlarda göstermektedir. $\mathrm{Bu}$ bağlamda bu çalışmada Türkiye'de sıklıkla yaşanan politik istikrarsızlığın diğer içsel ve dışsal değişkenlerle birlikte Türk bankacılık sistemi üzerindeki etkileri ortaya konulmaya çalışılacaktır. Böylece ele alınan değişkenlerin bankacılık sistemi üzerine etkileri incelenerek bankacılık sisteminin daha etkin çalışabilmesinin koşulları belirlenecektir. Öte yandan bilindiği üzere finansal kesimin temel amacı reel kesimin ihtiyaç duyduğu fonu sağlamaktır. Dolayısıyla daha etkin çalışacak finansal kesim reel kesimin de ihtiyaç duyduğu fonu daha uygun koşullarda sağlayarak ülke ekonomisinin büyümesi üzerinde pozitif bir etki yaratacaktır. Bu bağlamda çalışmanın amacı doğrultusunda politik istikrarsızlık ve politik istikrarsızlığın bankacılık sektörü üzerine ilişkin bilgi verilmiştir. Ardından literatür taramasına yer verilerek panel veri yöntemi ile ekonometrik çalışma sonucu Türkiye'de içsel ve dışsal değişkenlerle birlikte politik istikrarsızlığın bankacılık sektörü üzerine etkileri ortaya konulmaya çalışılmıştır. Çalışma sonuç ve politika önerileri ile son bulmaktadır. 
Tablo: 1

\section{Literatür Özeti}

\begin{tabular}{|c|c|c|c|c|c|}
\hline Yazarlar & Yıl & Yöntem & $\begin{array}{c}\text { Bağımlı } \\
\text { Değişkenler }\end{array}$ & Bağımsız Değişkenler & Sonuç \\
\hline $\begin{array}{l}\text { Demirgüç-Kunt } \\
\text { ve Huizinga }\end{array}$ & 1999 & Panel veri & $\begin{array}{l}\text { Net faiz marj1 ve } \\
\text { aktif kârlllığ1 }\end{array}$ & $\begin{array}{l}\text { Duran aktif, kredi, mevduat, faiz dış gider, yabancı } \\
\text { mülkiyeti, reel faiz, enflasyon, büyüme oranı, zorunlu } \\
\text { karşllı oranı, vergi oranı, mevduat sigorta sisteminin } \\
\text { varlığı, konsantrasyon, borsa piyasa kapitalizasyonu. }\end{array}$ & $\begin{array}{l}\text { 1988-1995 dönemi için } 80 \text { ülkedeki bankacillk sisteminin kârlarının incelendiği çalış̧mada, } \\
\text { sektör yoğunluğunun çok olduğu ülkelerde bankaların daha az kârlı olduğu, sermaye } \\
\text { yoğunluğu büyük olan bankaların kâr marjlarının daha yüksek olduğu, gelişmekte olan } \\
\text { ulkelerde yabancı bankaların daha kârlı olduğu ve enflasyonun banka kârlarını arttırdığ1 } \\
\text { tespit edilmisstir. }\end{array}$ \\
\hline Naceur ve Goaied & 2001 & Panel veri & Aktif kârlılığı & $\begin{array}{l}\text { İsggücü verimliliği, sermaye verimliliği, yatırım } \\
\text { hesabı/toplam aktifler }\end{array}$ & $\begin{array}{l}1980-1995 \text { dönemi için Tunus'ta faaliyet gösteren bankalar üzerine yapılan bu çalışmada, } \\
\text { isgücü ve sermaye verimliliklerini arttırma çabası gösteren ve aktiflerine oranla daha } \\
\text { yüksek miktarda yatı̈ım hesabına sahip olan bankaların daha yüksek performans } \\
\text { gösterdikleri belirlenmiştir. }\end{array}$ \\
\hline Kaya & 2001 & $\begin{array}{l}\text { Panel veri -iki } \\
\text { aşamalı } \\
\text { yöntem }\end{array}$ & Net faiz marj 1 & $\begin{array}{l}\text { Toplam varlıklar/M2, Cari işlemler dengesi/Merkez } \\
\text { Bankası rezervleri }\end{array}$ & $\begin{array}{l}\text { Toplam varlıklar/M2 oranındaki artış net faiz marjinı daraltmaktadır. Makroekonomik } \\
\text { yapıdaki sürdürülebilirliği temsil eden cari işlemler dengesi/Merkez Bankası rezervleri ile } \\
\text { net faiz marji arasında negatif bir ilişsi bulunmuştur. Cari işlemler dengesindeki } \\
\text { bozulmanın sistemin sürdürülebilirliği konusunda soru işaretleri yarattı̆̆ ve bu olumsuz } \\
\text { bekleyişin faiz marjlarının açılmasına neden olduğu öne sürülmektedir. }\end{array}$ \\
\hline $\begin{array}{l}\text { Guru, Staunton } \\
\text { ve } \\
\text { Balashanmugan }\end{array}$ & 2002 & Panel veri & Aktif kârll1ı̆̆ & $\begin{array}{l}\text { Likidite, sermaye yeterliliği, masraf yönetimi, } \\
\text { bankanın ortaklık yapısı, büyüklüğü, dış ekonomik } \\
\text { koşullar. }\end{array}$ & $\begin{array}{l}\text { Malezya'da 1986-1995 döneminde faaliyet gösteren bankaları incelediği çalışma, yüksek } \\
\text { banka kârlllı̆ının en iyi belirleyicisinin etkin harcama yönetimi olduğunu ortaya } \\
\text { koymuştur. Makroekonomik değişkenlerden yüksek faiz oranlarını, düşük banka kârlllı̆̆1 } \\
\text { ile iliskili ve enflasyonun banka performansı üzerinde pozitif etkisi olduğunu bulmuștur. }\end{array}$ \\
\hline Kaya & 2002 & $\begin{array}{l}\text { Panel veri -iki } \\
\text { aşamalı } \\
\text { yöntem }\end{array}$ & $\begin{array}{l}\text { Net faiz marji, } \\
\text { aktif ve özkaynak } \\
\text { kârllı̆ı̆1 }\end{array}$ & $\begin{array}{l}\text { Özkaynak, likidite, personel gideri, piyasa pay1, } \\
\text { mevduat, net takipteki alacak, menkul kıymet, yabanc1 } \\
\text { para pozisyonu }\end{array}$ & $\begin{array}{l}\text { Panel veri tekniği ve iki aşamalı yaklaşımın kullanıldığ çalışmada net faiz marjının mikro } \\
\text { belirleyicilerinden olan özkaynaklar, likidite, personel harcamaları, mevduatlar ve piyasa } \\
\text { payı anlamlı değişkenler olarak ortaya çıkmıştır. Makro belirleyicilerden ise enflasyon ve } \\
\text { konsolide bütce açı̆̆ istatistiksel olarak anlamlı bulunmustur. }\end{array}$ \\
\hline $\begin{array}{l}\text { Jiang, Tang, Law } \\
\text { ve Sze }\end{array}$ & 2003 & Panel veri & Aktif kârll1lı̆ı & $\begin{array}{l}\text { Karşıllk gideri, faiz dıssı gider, faiz dışı gelir, vergi } \\
\text { oranı, enflasyon, büyüme oranı, reel faiz. }\end{array}$ & $\begin{array}{l}\text { Hong Kong bankacillk sektörünün kârlarınn, makroekonomik değişkenlerden özellikle } \\
\text { deflasyona duyarlı olduğu, bankaya özgü unsurlardan ise operasyonel etkinliğin en } \\
\text { açklayıcı değisken olduğu ortaya konulmustur. }\end{array}$ \\
\hline Naceur & 2003 & Panel veri & $\begin{array}{l}\text { Net faiz marjı ve } \\
\text { aktif kârlılığ1 }\end{array}$ & $\begin{array}{l}\text { Ozkaynak, faiz dış1 gider, kredi, enflasyon, GSYH } \\
\text { büyüme oranı, aktif büyüklüğü, konsantrasyon, borsa } \\
\text { piyasa kapitalizasyon }\end{array}$ & $\begin{array}{l}\text { Aktif büyüklügüyle net faiz marjı arasinda negatif ilişki bulunmuş ve enflasyon ve büyüme } \\
\text { oranları gibi makroekonomik değişkenlerin banka net faiz marjı ve kârlllı̆̆ üzerinde } \\
\text { etkisinin olmadığ tespit edilmisțir. }\end{array}$ \\
\hline Tunay ve Silpar & 2006 & $\begin{array}{l}\text { Cok } \\
\text { değişkenli } \\
\text { regresyon } \\
\text { modeli ve } \\
\text { Panel veri }\end{array}$ & $\begin{array}{l}\text { Net faiz marjı, } \\
\text { aktif ve özkaynak } \\
\text { kârlılı̆̆ }\end{array}$ & $\begin{array}{l}\text { Faiz dışı gider, özkaynak, kredi, faiz dışı gelir, banka } \\
\text { büyüklüğ̈u, enflasyon, büyüme oranı, konsantrasyon, } \\
\text { bankacllık sektör büyüklügü, borsa piyasa } \\
\text { kapitalizasyon }\end{array}$ & 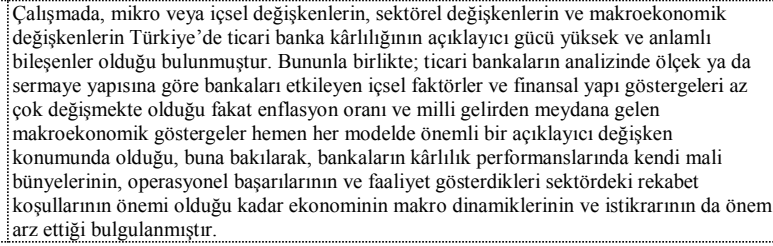 \\
\hline
\end{tabular}




\begin{tabular}{|c|c|c|c|c|c|}
\hline Yildiz & 2010 & $\begin{array}{c}\text { Anket ve } \\
\text { faktör analizi }\end{array}$ & $\begin{array}{l}\text { Mevduat payı, } \\
\text { aktif kârlllık, } \\
\text { piyasa değeri } \\
\text { defter değeri } \\
\text { oranı }\end{array}$ & $\begin{array}{l}\text { Subjektif Performans Ölçeği: Bankamız sektörde bir } \\
\text { numaradır. Kârlılığımız sürekli olarak artmaktadır. } \\
\text { Bankamızın itibarı (imajı) yüksek düzeydedir. Yeni } \\
\text { ürün ve proje başlatılımasındaki başarı oranı yüksektir. } \\
\text { Bankamızın genel performansı düşüktür. }\end{array}$ & 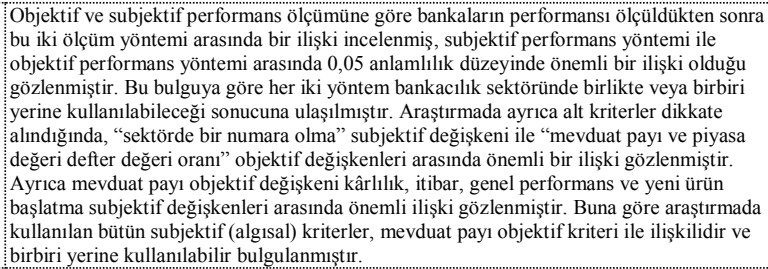 \\
\hline Taşkın & 2011 & Panel veri & $\begin{array}{c}\text { Net faiz marjı, } \\
\text { aktif kârll11ı̆g1, } \\
\text { özkaynak kârlllığ }\end{array}$ & $\begin{array}{l}\text { İşsel Belirleyenler: (Toplam Krediler/Toplam } \\
\text { Aktifler, Aktif Büyüklüğü, Özkaynaklar /Toplam } \\
\text { Aktifler, Özel Karşıllklar/ Toplam Krediler, Personel } \\
\text { Giderleri/ Toplam Gelirler, Bilanço Diş1 Faaliyetler/ } \\
\text { Toplam Aktifler), Makro Belirleyenler (Kişi Başna } \\
\text { Dusşen Gayri Safi Milli Hâsla, Sanayi Üretim } \\
\text { Endeksi, Faiz Oranı, Enflasyon Oranı, 2001 Krizi) }\end{array}$ & 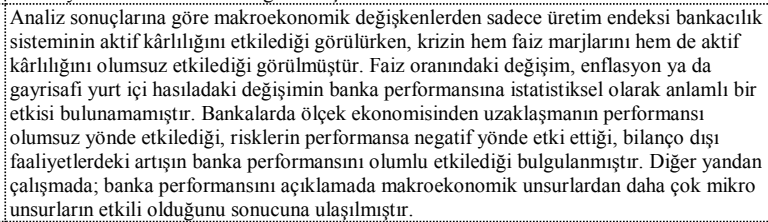 \\
\hline $\begin{array}{c}\text { Lartey, Antwi, } \\
\text { Boadi }\end{array}$ & 2013 & Panel veri & Aktif kârlılığı & Likidite oranı & $\begin{array}{l}\text { Gana pay piyasasında faaliyet gösteren } 9 \text { bankanın } 2005-2010 \text { yilları arasnda kârllık ile } \\
\text { likidite arasındaki iliski ölcülmüstür. İki değisken arasındaki iliski negatif bulunmustur. }\end{array}$ \\
\hline Aydın ve Kök & 2013 & $\begin{array}{l}\text { Veri zarflama } \\
\text { analizi ve En } \\
\text { Küçük Kareler } \\
\text { Yöntemi }\end{array}$ & $\begin{array}{l}\text { Teknik Etkinlik } \\
\text { Düzeyleri }\end{array}$ & $\begin{array}{l}\text { Likit Aktifler/Toplam Aktifler, Personel } \\
\text { Harç/Personel Sayısı, Şube Sayıs, Toplam Aktifin } \\
\text { Sektör İçindeki Pay1, Toplam Krediler / Toplam } \\
\text { Mevduat,Toplam Mevduat / Toplam Aktifler, } \\
\text { Sermaye Yeterlilik Oranı, Aktif Kârllılığ1 }\end{array}$ & $\begin{array}{l}\text { Veri zarflama analizi yöntemi ile elde edilen teknik etkinlik bulguları, Türk bankacillk } \\
\text { sisteminde önemli bir etkinsizlik sorununa işaret etmiştir. Etkinsizliğin kaynaklarının } \\
\text { belirlenmesine yönelik başvurulan Tobit modeli sonuçları değerlendirildiğinde her bir } \\
\text { karar alma birimi açısndan: ölçek büyüklüğü, portföy seçiminde kredi ağılı̆ı̆ı, aktif } \\
\text { kalitesinde iyileşme, likit aktif oranı ve sermaye yeterliliği rasyosundaki artış etkinsizliği } \\
\text { azalttığı, buna karşın, karar alma birimlerinin mülkiyetinin kamu odaklı oluşu, personel } \\
\text { harcamalarındaki ve şube sayısındaki artış etkinsizliği arttırdı̆ı bulgulanmıştır. }\end{array}$ \\
\hline $\begin{array}{l}\text { Ayaydın ve } \\
\text { Karaaslan }\end{array}$ & 2015 & Panel veri & $\begin{array}{l}\text { Aktif kârlılık } \\
\text { oranı, satış } \\
\text { kârlılık oranı, } \\
\text { satış büyüme } \\
\quad \text { oranı } \\
\text { ve TobinQ oranı }\end{array}$ & $\begin{array}{l}\text { Politik belirsizlik (seçim 2009, 2010, 2011), firma } \\
\text { büyüklüğ̈ünü temsilen toplam aktiflerin doğal } \\
\text { logaritmas, toplam borçlar / toplam aktifler, (Dönen } \\
\text { varlıklar - kısa vadeli borçlar) / toplam aktifler, net } \\
\text { satı̧lar / toplam aktifler, GSYH büyüme oranı }\end{array}$ & $\begin{array}{l}\text { Politik belirsizliğin reel ekonominin performansını olumsuz etkilediği sonucuna } \\
\text { ulaşlıışıı. Büyük firmaların ölçek ekonomisinden yararlanarak birim maliyetlerini } \\
\text { azaltma yoluyla finansal performanslarıı artırdıkları ve aktiflerini verimli kullanan } \\
\text { firmaların finansal performanslarını olumlu etkiledikleri bulunmuştur. Buna karşın, } \\
\text { firmaların kullandıkları borç kaynaklarını verimli kullanamadıkları, kaldıracın pozitif } \\
\text { etkisinden yararlanamadıkları bulgulanmıștı. }\end{array}$ \\
\hline
\end{tabular}




\section{Literatür Taraması}

Literatür taraması yapıldığında bankaların performansını analiz eden yayınlanmış ulusal ve uluslararası çok sayıda araştırma bulunmaktadır. Bankaların kârılığını analiz eden literatürün bir kısmının tek bir ülke üzerine odaklanmış olduğu, bir kısmının ise birçok ülke üzerinde yoğunlaştığı görülmektedir. Literatürde yer alan bu çalışmaların bir kısmı yukarıdaki tabloda özet olarak sunulmuştur ${ }^{1}$.

\section{Banka Performans Ölçümünün Modellenmesi}

Her firma gibi bankaların da amaç fonksiyonlarının temeli, kârı maksimize etmektir. Kârı maksimize etmenin iki ana değişkeni vardır: Bunlar "gelirlerin maksimizasyonu" ve "giderlerin minimizasyonu" şeklindedir. Bu nedenle, bankalar da aşağıdaki maksimizasyon sorunuyla karşı karşıyadırlar.

$$
\pi=\max (R-C) \quad \pi>0
$$

Fonksiyonda; $R$ toplam gelirleri, C toplam maliyeti ve $\pi$ kârı göstermektedir.

Literatür taramasında da görüldüğü gibi banka kârlılığının ölçülmesinde; kâr marj1, net faiz marj1, TobinQ, aktiflerden sağlanan getiri (return on assets/ROA), özkaynaklardan sağlanan getiri (return on equity/ROE) gibi farklı değişkenler kullanılmıştır.

Diğer yandan literatürde performans modellemelerinin ikiye ayrıldığ 1 görülmektedir. Birinci tür modellemelerde; sadece aktif kârlılığı (ROA), özkaynak kârlıllğı (ROE) ve net faiz marjı (NIM) gibi temel kârlılık ve performans ölçütlerinin içinde yer alan unsurlara ayrıştırılmasına dayanan basit model kalıpları test edilmektedir. Yukarıda da incelenen Jiang, Tang, Law ve Sze'nin (2003) çalışması bu yaklaşımın tipik bir örneğidir. Jiang, Tang, Law ve Sze'nin (2003) çalışmasında, banka kârlılığının anahtar unsuru olarak aktif kârlılığı (ROA) kabul edilmiş ve bileşenlere ayrılmıştır.

İkinci tür modellemeler daha karmaşıktır. Bunlar performansı (kârlılığı) banka içi (içsel) ve banka dışı (dışsal) faktörlerin etkisine göre ikili bir yapıda analiz etmektedir. İçsel faktörler, bankanın kontrol edebileceği kendi bünyesindeki ölçütlerden meydana gelmektedir. Örneğin, likit aktifler/toplam aktifler, toplam krediler ve alacaklar/toplam aktifler, sermaye/toplam aktifler, genel giderler/toplam aktifler ve likidite oranları içsel faktörlerin belli başlılarıdır. Dışsal faktörler ise, bankanın kontrolü altında olmayan ve bu

1 Tabloda verilen literatürün yanı sıra daha geniş bilgi için şu çalışmalara da bakılabilir: Ho ve Saunders (1981), Molyneux ve Thomton (1992), Boyd ve Runkle (1993), Eken, M. Hasan (1997), Bashir (2000), Cingi ve Tarım (2000), Abreu ve Mendes (2002), Gerlach, Peng ve Shu (2005), Wu, Chen ve Shiu (2007), Pasiouras ve Kosmidou (2007), Athanasoglou, Brissimis ve Delis (2008), Doğru (2011). 
nedenle de veri almak zorunda olduğu unsurlardır. Makroekonomik göstergelerdeki değişmeler ve finansal yapıya ilişkin ölçütler bu kapsamdadır (Tunay \& Silpar; 2006a: 11). Bunlar Demirgüç-Kunt-Huizinga'nın (1999, 2000), Kaya'nın (2002), Naceur'un (2003), Tunay-Silpar'ın (2006b) çalışması çerçevesinde aşağıdaki doğrusal fonksiyondaki gibi birlikte ifade edilebilmektedir:

$$
\pi_{i, t}=f\left(B C_{i, t}, M_{t}, F S_{t}\right)
$$

Fonksiyonda, $\pi_{i, t} t$ döneminde $i$ bankasının alternatif performans ölçütlerini, $B C_{i, t} t$ döneminde $i$ bankasının içsel faktörlerini, $M_{t}$ makroekonomik değişkenleri ve $F S_{t}$ finansal göstergeleri simgelemektedir. Bankaların performanslarını etkileyen içsel faktörler şöyle gösterilebilir:

$B C_{i, t}=f($ Likit Aktifler/Toplam Aktifler, Toplam Krediler ve Alacaklar/

Toplam Aktifler, Özkaynaklar/Toplam Aktifler, Genel Giderler/Toplam Aktifler,

$\log$ (Toplam Aktifler), Sermaye Yeterlilik Rasyosu)

Banka performansını etkileyen dışsal değişkenler makroekonomik ve finansal değişkenlerdir. Makroekonomik değişkenler; enflasyon, sanayi üretim endeksi ve GSYİH büyüme oranıdır.

$$
M_{t}=f(\text { Enflasyon, Sanayi Üretim Endeksi, GSYİH Büyüme Oranı) }
$$
gösterilebilir:

Bankaların performanslarını etkileyen finansal değişkenler ise aşağıdaki gibi

$F S_{t}=f($ Kur oynaklı̆̆l, bankaların nispi büyüklükleri,

finansal piyasaların gelişmişliği, bankaların toplamaktiflerinin milli gelire oranı, yoğunlaşma oranı, Merkez Bankası borç verme faiz oranı)

Bankaların nispi büyüklükleri (relative size), bankaların toplam mevduatlarının hisse senetleri piyasası kapitalizasyon oranına bölünmesiyle bulunur. Finansal piyasaların gelişmişliğini belirlemek için milli gelir hisse senetleri piyasası kapitalizasyon oranına (market capitalization) bölünür. Yoğunlaşma oranı (concentration ratio) sektördeki en büyük beş bankanın toplam aktiflerinin toplam banka aktiflerine oranlanmasıyla hesaplanır.

Çalışmamızda, bu yaklaşımlar referans alınarak bankaların performans ölçütü olarak aktif kârlılık (ROA) alınmıştır. Aktif kârlılığı etkileyen tahminciler hem banka içi hem de banka dışı faktörlere göre ayrıştırılmış ve panel veri modeli ile belirlenmiştir. Devam eden bölümde, analizde kullanılan değişkenler ve veri setine yer verilmektedir. 


\section{Veri Seti ve Değişkenlerin Belirlenmesi}

Çalışma, 2002q4 -2015q2 yılları arasında çeyreklik verilerle Türkiye'de faaliyet gösteren tüm ticari bankaları kapsamaktadır. Ancak analiz dönemi içerisinde verileri olmayan veya eksik olan, sektöre sonradan giren veya tek şubeli/çok küçük ölçekli olan bazı bankalar analiz dışında tutulmuştur. Bu bankalar ayıklandıktan sonra geriye kalan toplam 23 ticari banka analize dâhil edilmiştir. Bankalar ile ilgili olan veriler (içsel değişkenler) Türkiye Bankalar Birliği’nden, makroekonomik ve finansal değişkenlere ilişkin veriler ise Türkiye Cumhuriyeti Merkez Bankası ile Türkiye İstatistik Kurumu (TÜIK) internet sitelerinden alınmıştır. Politik istikrarsızlık göstergesi olarak Politik Risk Grubu (PRS Group) tarafindan hazırlanan "Uluslararası Ülke Risk Rehberi (ICRG-International Country Risk Guide)"nden alınan "Politik Risk Endeksi” kullanılmıştır.

Çalışmamızda banka performansı, yukarıda değinilen çalışmalar baz alınarak denklem 2'deki modele göre ölçülmüştür. Buna göre modele dâhil edilen performans ölçütü ile içsel ve dışsal değişkenlere devam eden bölümde yer verilmiştir.

\section{Performans Ölçütü}

Banka kârlılığının temel göstergelerinden biri aktif kârlılı̆̆ıdır:

$$
\text { ROA }=\frac{\text { Net Gelir }}{\text { Toplam Aktifler }}
$$

ROA, bankanın varlıklarının kâr elde etmede hangi faaliyetlerde bulunduğunu göstermekte ve banka yönetimine ilişkin bir etkinlik kriteri olarak kabul edilmektedir (Taşkın, 2011: 293). ROA, banka tarafından kullanılmış tüm varlıkların getirisi üzerinde yoğunlaşmaktadır. Bu yönüyle çalışmada aktif kârlılığın (ROA) belirleyenleri analiz edilmektedir.

\section{Performansı Belirleyen İçsel Değişkenler}

Ticari bankaların performansının içsel belirleyicileri olarak bu çalışmada toplam krediler/toplam aktifler, aktif büyüklüğü ve sermaye yeterliliği rasyosu kullanılmaktadır.

- Toplam Krediler/Toplam Aktifler (TKTA): Geleneksel yaklaşıma göre bankalar, fon arz edenler ve fon talep edenler arasinda aracı görevindedir. Genel anlamda, mevduatlar krediye dönüştürüldüğü sürece net faiz marjı ve kârlllık daha da yükselecektir. Ne var ki, bir banka, toplam kredi/toplam aktif oranını arttırırken daha çok risk alıyorsa, bu bankanın kârlarının düşmesine de neden olabilmektedir.

- $\quad$ Aktif Büyüklüğü (LRTA): Bankanın aktif büyüklüğü, performansının önemli belirleyicilerinden biridir. Literatürden bilindiği üzere banka ölçeklerindeki 
Ay Yalçınkaya, A.E. \& S. Şanlısoy \& Ü. Aydın (2016), "Türk Bankacılık Endüstrisinde

Performansın Belirleyenleri ve Politik İstikrarsızlık İlişkisi”, Sosyoekonomi, Vol. 24(27), 161-182.

farklılıklar, bankalara ölçek ekonomilerine dayanan avantajlar veya dezavantajlar getirebilir. Büyük ölçekli ve çok şubeli bankalar, finansal kaldıraç etkisini daha yoğun kullanabilirler. Buna bağlı olarak ortalama kaynak maliyetlerini minimize ederek daha fazla kâr sağlayabilirler. Ayrıca gelişmiş Ar-Ge bölümleri ile daha etkin yönetim yapabilirler. Diğer taraftan, çok şubeli oluşlarının yardımıyla tüketici kredileri ve kredi kartları gibi riski geleneksel kredilere göre oldukça düşük olan bireysel kredilerle aktiflerden elde ettikleri getirileri maksimum kılabilirler. Ek olarak, çok şubeli olmaları ücret ve komisyon kazandıran bankacılık hizmetlerinde de onlara avantaj sağlar. Büyük ölçekli bankalar, hem endüstri içinden hem de dışarıdan gelen değişim ve şoklara karşı yapı, sistem ve süreç bağlamıyla varlıklarını korumakta daha üstündürler. Bir başka deyişle, şoklara ve yasal değişimlere karşı önlem almada ve uyum sağlamada daha yetkindirler. Ayrıca, büyük ölçekli bankalar, oligopolistik yapısını kullanarak "içerden bilgilenenler" konumunda oldukları ve piyasayla ilgili olarak herkes tarafindan bilinmeyen bilgileri elde etme yetkinliklerine sahip bulundukları için fiyatların hangi yönde değişeceği fikri ve ön bilgiden hareketle portföylerini esnek bir şekilde düzenleme avantajına sahiptirler. Büyük ölçekli firmaları izleyen takipçi firmalar için de "bandwagon etkisi" oluşturarak sürü psikolojisi yaratabilmektedirler. Ancak, firma ölçeğinin büyümesi, X-etkinsizliği adı verilen, yönetimsel etkinsizliğe de neden olabilmektedir (Aydın, 2010: 287). Küçük ölçekli bankalar bu tür avantajlara sahip değillerdir. Riskli aktif-pasif yönetimi stratejileri izlemeye uygun bir yapıları da yoktur. Ancak küçük ölçekli bankalar da, şube ve personel sayılarının azlığı nedeniyle ciddi sabit maliyet avantajları taşımaktadır. Bunlar çok şubeye ve personele gereksinim göstermeyen butik bankacılık (boutique banking), ihtisas bankacılığı (special banking) gibi kurumsal bankacılık uygulamaları için elverişli bir yapıya sahiptirler. Kurumsal bankacılık uygulamalarına; kurumsal krediler, dış ticaretin finansmanı işlemleri (akreditif açma v.s.), halka arza aracılık, kurumsal fon yönetimi ve danışmanlık gibi hizmetlere girmektedir (Tunay ve Silpar, 2006: 4). Aktif büyüklüğü ile ilgili ampirik çalışmaların sonuçları çelişkilidir. Literatürde büyük bankaların ölçek ekonomisinden uzaklaştığını bulmuş olan çalışmalar da mevcuttur (Taşkın, 2011: 294).

- $\quad$ Sermaye Yeterliliği Rasyosu (SY) aşağıdaki formülle hesaplanmaktadır:

Özsermaye / Riskteki Aktifler + [(Piyasa + Kredi + Operasyonel Riskleri $) *$ $12,5]$

Bankanın yaşayabileceği şokların üstesinden gelmesi için yeterli olan özkaynak miktarını simgelemektedir. $\mathrm{Bu}$ oranın yüksek olması bankanın, dış kaynaklara olan bağımlılı̆̆ını azaltması ve yüksek kârlara ulaşmasına yardımcı olmaktadır. Özkaynaklar, bankaların ekonomik bir değer oluşturması yönünde bir güvence oluşturmaktadır. Bu nedenle, yeterli bir özkaynak düzeyine sahip bankaların yetkinliği artabilecektir. Ekonomik karar birimleri bu tip bankalara daha fazla güven duyarak mevduat ve kredi taleplerini bu 
bankalara yönlendireceklerdir. Ancak, bankaların, düşük risk ağırlıklı varlıklar ve buna karşılık yüksek özkaynak bulundurması dolayısıyla SY'nin çok yüksek olması finansmanda kullanılan klasik "daha fazla risk, daha fazla getiri” teorisiyle çelişmesine neden olmakta ve performansın düşmesine yol açabilecektir. Böylesi bir durumda, bankaların ahlaki tehlike ve ters seçim riskini azaltmak için üretimini kıstığını söyleyebilmek mümkündür. Kaya (2002)'nın elde ettiği sonuçlar; bankaların kârlılık performanslarında kalıcılığı sağlamak için güçlü bir sermaye yapısının şart olduğunu göstermektedir.

\section{Performansı Belirleyen Dışsal Değiş̧kenler (Makroekonomik ve Finansal)}

İncelenen literatür, bankaların faaliyette bulunduğu çevrenin banka performansını etkilediğini göstermektedir. $\mathrm{Bu}$ nedenle bankanın kontrol edemediği, ancak kendisinin etkilendiği birçok makroekonomik ve finansal değişken uygulamalı çalışmalarda dikkate alınmıştır. Dolayısıyla, bu çalışmada Türkiye ekonomisinde ve finansal sektörde yaşanan genel durumun banka performansını etkilemesi beklenmekte, bu beklentiyle de aşağıdaki değişkenler modele dâhil edilmektedir:

- GSYIH Büyüme Oranı (GDP): Bir ekonomideki toplam iktisadi faaliyetlerdeki değişimi göstermesi bakımından en yaygın kullanılan makroekonomik değişkendir. Çalışmada GSYİH'daki çeyreklik büyüme oranları mevsim ve takvim etkilerinden arındırılmış olarak dikkate alınmıştır. Bu büyüme oranının, kredilerin arz ve talebine etki ettiği düşünülmekte ve banka performansıyla arasında pozitif bir ilişki beklenmektedir.

- TCMB Borç Verme Faiz Oranı (BVFO): Likidite sıkışıklığına düşen bir bankanın, Merkez Bankası'ndan kısa vadeli borçlanmak için ödemeyi kabul ettiği faiz oranı demektir. Faiz koridorunun üst bandını oluşturmakta olup bankanın maliyetlerinde bir artış yaratacağından banka performansıyla arasında negatif bir ilişki beklenmektedir.

- Kur Oynaklığı (KUROYN): Türkiye'deki bankaların yabancı para cinsinden gerek yükümlülükleri gerekse varlıkları ağırlıklı Dolar ve Euro olduğu için ikisinden oluşan bir sepet kur oluşturuldu. Oluşturulan sepet kurun oynaklığı hesaplanarak döviz fiyatlarının banka performansı üzerindeki etkisi izlendi. Dolar ve Euro kur sepeti değeri için (\%50\$ + \%50€) yöntemine başvuruldu. Buna göre, TCMB kapanış fiyatları üzerinden kur sepeti değeri = $(1 U S D+1$ Euro $) / 2$ formülüyle hesaplanmakta, hesaplanan sepet kurun oynaklığı ise $\left(X-\bar{X}^{2}\right.$ formülüyle bulunmaktadır.

- Politik Istikrarsızlık (DPRI) göstergesi olarak kullanılan politik risk endeksinin amacı, ülkenin politik istikrarına ilişkin bir değerlendirme aracı sağlamaktır. Bu noktada politik risk bileşenleri olarak adlandırılan, önceden hazırlanmış faktörler grubuna risk puanları verilmektedir. Her bir bileşene verilen en düşük puan sıfır iken; en yüksek puan, bileşenin, tüm politik risk değerlendirmesi için verili olduğu sabit ağırlığa göre değişmektedir. 
Politik risk endeksi, gerek politik, gerekse sosyal tutumları kapsayan 12 adet ağırlıklandırılmış değiş̧keni içermektedir. Politik risk endeksi; hükümet istikrarı, sosyoekonomik koşullar, yatırım profili, iç çatışmalar, dış çatışmalar, yolsuzluk, politikada ordunun etkisi, dinsel gerilimler, hukuk ve düzen, etnik gerilimler, demokratik hesap verebilirlik ve bürokrasinin niteliği faktörlerinin her birine yönelik risk puanlarını değerlendirerek bir ülkenin politik istikrarını analiz etme aracıdır. Risk dereceleri, en düşük riski gösteren 100 puan ile en yüksek riski gösteren 0 puan arasında değişmektedir.

\section{Politik risk endeksi:}

- $\quad(\% 0,0$ - \%49,9) aralığında ise çok yüksek politik riski,

- $\quad(\% 50,0$ - \%59,9) aralığında ise yüksek politik riski,

- $\quad(\% 60,0$ - \%69,9) aralığında ise orta düzey politik riski,

- $\quad(\% 70,0$ - \%79,9) aralığında ise düşük politik riski,

- $\quad$ \% 80,0 üzerinde ise çok düşük politik riski ifade etmektedir.

Çalışmamızda banka performansının belirleyeni olarak alınan politik risk endeksi, hem bağımsız değişkenler hem de bağımlı performans değişkeni üzerinde ortak etki yarattığından dışsal bir kukla değişken olarak modele dâhil edilmiştir. Politik risk endeksinin yüzde 60 ve üzerinde olan değerine 0 , yüzde 59,9 ve altında olan değerine 1 atanmış ve DPRI kukla değişkeni oluşturulmuştur. Buna göre politik risk endeksinin yüzde 59,9 ve altında olan değeri yüksek ve çok yüksek politik riski verdiğinden politik risk ve istikrarsızlığın banka performansı üzerindeki etkisinin negatif olması beklenmektedir.

Yapılan literatür araştırması sonucunda politik istikrarsızlığın, Türk bankacılık sektöründeki bankaların performansına etkisi üzerine çalışmaya rastlanmamıştır. Bu çalışma diğer içsel ve dışsal değişkenlerin yanı sıra politik istikrarsızlığın bankaların finansal performanslarını nasıl etkilediği yönünde literatürdeki bu boşluğu doldurmayı hedeflemektedir. Çalışma bu yönüyle literatüre katkıda bulunmaktadır.

\section{Yöntem}

Panel veri analizi, zaman boyutuna ait kesit verileri kullanılarak ekonomik ilişkilerin tahmin edilmesine olanak veren bir yöntemdir. Bu analizde zaman serileri ile kesit serileri bir araya getirilerek, hem zaman hem de kesit boyutuna sahip veri seti oluşturulmaktadır. Panel veri modelleri, n sayıda ekonomik birim ve her birime ait T sayıda gözlem içermektedir. Panel veri analizi sadece zaman serisi veya yatay kesit verileriyle çalışmanın yeterli olmadığ 1 durumlarda her iki veri setiyle eş anlı olarak çalışma olanağ 1 sağlamaktadır (Greene, 2003: 283). Panel veri regresyon modelinin basit biçimdeki gösterimi şu şekildedir (Greene, 2003: 285): 


$$
\mathrm{Y}_{\text {it }}=\alpha_{\mathrm{i}}+\beta_{1} \mathrm{X}_{1 \mathrm{it}}+\varepsilon_{\text {it }} \quad \mathrm{i}=1,2, \ldots, \mathrm{N} \quad \mathrm{t}=1,2, \ldots, \mathrm{T}
$$

(8) nolu denklemde i alt simgesi, hane halkı, firma, ülke gibi yatay kesit boyutunu ifade ederken, $\mathrm{t}$ alt simgesi, zaman serisi boyutunu ifade etmektedir. Denklemde $\mathrm{y}_{\text {it }}$ modele ait bağımlı değişkenleri, $X_{1 i t}$ bağımsız değişkenleri, $\alpha_{i}$ sabit kesişim katsayısını ve $\varepsilon_{i t}$ hata terimini göstermektedir (Baltagi, 2005: 11-12).

Panel veri analiz yöntemlerinde karar verilmesi gereken önemli konulardan biri sabit etkiler modellerinin mi yoksa tesadüfi etkiler modellerinin mi kullanılacağıdır (Baltagi, 2005: 19-20). Bu durumda sabit etkili model parametre tahmincileri ile tesadüfi etkili modelin parametre tahmincileri arasındaki farkın istatistiksel olarak anlamlı olup olmadığının incelenmesi gerekmektedir. Dolayısıyla tesadüfi etkiler modelinin mi yoksa sabit etkiler modelinin mi kullanılacağı Hausman testi ile ortaya koyulabilir. Hausman testi; birim etki dolayısıyla hata terimi ile açıklayıcı değişkenler arasında korelasyon olup olmadığını yani tesadüfi etkili modelin uygun olup olmadığını ölçmektedir. Hausman Testi (1978) ile sabit etkiler modeli parametre tahmincileri ile tesadüfi etkiler modelinin parametre tahmincileri arasındaki farkın istatistiksel olarak anlamlı olup olmadığ incelenmektedir. Hausman test istatistiğinin hipotezleri şöyledir:

$\mathrm{H}_{0}: \mathrm{E}\left(\varepsilon_{\mathrm{it}} \mid \mathrm{X}_{\mathrm{it}}\right)=0$ kesit verisi ve zaman serisi etkileri rassaldır.

$H_{1}: E\left(\varepsilon_{i t} \mid X_{i t}\right)=0$ kesit verisi ve zaman serisi etkileri sabittir.

$\mathrm{Bu}$ testte sıfir hipotezinin kabul edilmesi rassal etkiler modelinin sabit etkiler modeline tercih edilmesi gerektiğini göstermektedir. Hausman testinde, tesadüfi etkiler modelinden elde edilen katsayılar ile sabit etkiler modelinden elde edilen katsayıların aynı olduğunu gösteren boş hipotezin reddedilmesi sabit etkiler modelinin reddedilememesi ise tesadüfi etkiler modelinin daha etkin sonuçlar verdiğini göstermektedir. Sonuç olarak yöntem temelinde sabit ve tesadüfi etkiler modelinin belirlenmesinde Hausman (1978) tarafından geliştirilen testten yararlanılmıştır.

Yatay kesit gözlemlerin belli bir zaman dönemi içinde bir araya getirilerek oluşturulan panel veri analizi, beraberinde zaman serisi özelliklerini ve sorunlarını da getirmektedir. Maddala'ya (1999) göre, günümüzde birim kök testleri uygulamadan zaman serisi analizi yapmak neredeyse olanaksızdır. Panel veri setinin zaman boyutu içermesi nedeniyle, panel verilerde birim kökleri araştırmak ve panel birim kök testleri uygulamak gereklidir. Çünkü panel verilerde birim kök varsa sonuçlara şüphe ile bakmak gerekmektedir (Maddala, 1999: 418). Eğer verilerde birim kökün varlığı tespit edilirse, sahte regresyon sorunu zaman serisi analizlerinde olduğu gibi panel veri analizinde de ortaya çıkmaktadır. Panel birim kökün var olması durumunda, özellikle uzun dönemli ilişkiyi ortaya çıkarmak için panel eşbütünleşme (koentegrasyon) yaklaşımı kullanılmaktadır (Frantzen, 2002: 286). 


\section{Bulgular}

Çalışmada kullanılan bağımlı ve bağımsız değişkenlerin tanımlayıcı istatistikleri ile panel sabit etkiler modeli tahmin sonuçları aşağıda yer almaktadır.

\subsection{Modele İlişkin Tanımlayııı İstatistikler}

Model sonuçlarına geçmeden önce, panel veri analizinde 2002q4-2012q2 dönemine ilişkin 23 bankanın kullanılan bağımlı ve bağımsız değişkenlerin temel bazı tanımlayıcı istatistikleri Tablo 2'deki gibidir.

Tablo: 2

\section{Değişkenlere İlişkin Tanımlayıcı İstatistikler}

\begin{tabular}{|l|r|r|r|r|r|r|r|}
\hline & \multicolumn{1}{|c|}{ SY } & \multicolumn{1}{c|}{ TKTA } & \multicolumn{1}{c|}{ LRTA } & \multicolumn{1}{c|}{ KUROYN } & \multicolumn{1}{c|}{ GDP } & \multicolumn{1}{c|}{ BVFO } & \multicolumn{1}{c|}{ DPRI } \\
\hline Ortalama & 21,1551 & 50,2167 & 15,5833 & 0,1269 & 1,3015 & 15,3823 & 0,6078 \\
\hline Medyan & 16,5773 & 54,5396 & 15,5282 & 0,0565 & $-2,1387$ & 12,0000 & 1,0000 \\
\hline Maksimum & 148,1658 & 87,8415 & 18,5040 & 0,9143 & 21,6566 & 38,0000 & 1,0000 \\
\hline Minimum & 3,6233 & 0,0781 & 10,2133 & $5,57 \mathrm{E}-0.6$ & $-14,0154$ & 6,6667 & 0,0000 \\
\hline Standart sapma & 13,6867 & 18,4816 & 1,7578 & 0,1823 & 9,6486 & 7,1326 & 0,4884 \\
\hline Çarpıkık & 3,5157 & $-0,6518$ & $-0,1452$ & 2,4872 & 0,2301 & 0,9513 & $-0,4418$ \\
\hline Basıklık & 19,7323 & 2,6565 & 1,9571 & 9,1864 & 1,6983 & 3,3931 & 1,1951 \\
\hline Jarque-Bera & 16099,88 & 88,8323 & 57,2807 & 3079,991 & 93,1597 & 184,4812 & 197,3615 \\
\hline Prob. & 0,0000 & 0,0000 & 0,0000 & 0,0000 & 0,0000 & 0,0000 & 0,0000 \\
\hline Gözlem sayıSı & 1173 & 1173 & 1173 & 1173 & 1173 & 1173 & 1173 \\
\hline
\end{tabular}

Hausman (1978) testi sonuçlarına göre, sabit etkiler modeli rassal etkiler modeline göre daha uygun çıkmıştır. Bu nedenle, sabit etkiler modeli esas alınmıştır.

Tablo: 3

\section{Hausman Testi}

\begin{tabular}{|l|l|l|}
\hline H0: Rassal etkiler modeli geçerli & \multicolumn{2}{|c|}{} \\
\hline H1: Sabit etkiler modeli geçerli & \multicolumn{2}{|c|}{ H0 red. H1 kabul. Sabit etkiler modeli geçerlidir. } \\
\hline Hausman test istatistiği & Chi kare: 21,03 & 0,0003 \\
\hline
\end{tabular}

Im, Pesaran, Shin (2003) ve Levin, Lin, Chu (2002) birim kök testlerinin sonuçları genel olarak değerlendirildiğinde, LRTA ve KUROYN dışındaki analize dâhil olan değişkenlerin düzeyde durağan, yani I(0) oldukları görülmektedir. LRTA değişkeninin Levin, Lin Chu birim kök testine göre durağan olduğu, KUROYN değişkeninin ise her iki birim kök testi sonucunda I(1) olduğu, yani durağan olmadığı görülmüştür. Bu nedenle, KUROYN değişkeninin farkı alınarak, durağan haliyle modele dâhil edilmiştir. 


\section{Tablo: 4}

\section{Birim Kök Testleri}

\begin{tabular}{|l|r|r|r|r|r|r|}
\hline & \multicolumn{3}{|c|}{ Im, Peseran, Shin Birim Kök Testi } & \multicolumn{2}{c|}{ Levin, Lin, Chu Birim Kök Testi } \\
\hline \multicolumn{1}{|c|}{ Değișkenler } & W İstatistiği & \multicolumn{1}{c|}{ Prob. } & \multicolumn{1}{c|}{ Sonuç } & \multicolumn{1}{c|}{ t İstatistiği } & \multicolumn{1}{c|}{ Prob. } & \multicolumn{1}{c|}{ Sonuç } \\
\hline SY & $-4,9250$ & 0,0000 & $\mathrm{I}(0)$ & $-4,5481$ & 0,0000 & $\mathrm{I}(0)$ \\
\hline TKTA & $-2,4784$ & 0,0066 & $\mathrm{I}(0)$ & $-5,1619$ & 0,0000 & $\mathrm{I}(0)$ \\
\hline LRTA & 1,5677 & 0,9415 & $\mathrm{I}(1)$ & $-3,8218$ & 0,0001 & $\mathrm{I}(0)$ \\
\hline KUROYN & 18,3697 & 1,0000 & $\mathrm{I}(1)$ & 22,8704 & 1,0000 & $\mathrm{I}(1)$ \\
\hline GDP & $-115,595$ & 0,0000 & $\mathrm{I}(0)$ & $-127,956$ & 0,0000 & $\mathrm{I}(0)$ \\
\hline BVFO & $-4,2277$ & 0,0000 & $\mathrm{I}(0)$ & $-5,6610$ & 0,0000 & $\mathrm{I}(0)$ \\
\hline
\end{tabular}

\subsection{Panel Sabit Etkiler Modeli Tahmin Sonuçları}

Çalışmada kullanılan panel sabit etkiler modeli şu şekildedir:

$$
\begin{aligned}
& R O A=c+\beta_{1} . S Y+\beta_{2} . T K T A+\beta_{3} . L R T A+\beta_{4} . D K U R O Y N+\beta_{5} . G D P+\beta_{6} . B V F O+ \\
& \beta_{7} . D P R I+\varepsilon
\end{aligned}
$$

\section{Tablo: 5}

\section{Panel Sabit Etkiler Modeli}

\begin{tabular}{|l|r|r|r|}
\hline \multicolumn{1}{|c|}{ Bağımlı Değişken: ROA } & \multicolumn{1}{c|}{ Katsayı } & \multicolumn{1}{c|}{ Standart Hata } & \multicolumn{1}{c|}{ t Değeri } \\
\hline Sabit & $-6,3572$ & 1,9684 & $-3,23(0,001)^{*}$ \\
\hline SY & 0,0422 & 0,00468 & $9,02(0,000)^{*}$ \\
\hline TKTA & 0,0451 & 0,00484 & $9,32(0,000)^{*}$ \\
\hline LRTA & 0,2610 & 0,12509 & $2,09(0,037)^{* *}$ \\
\hline DKUROYN & $-1,6674$ & 0,35903 & $-4,64(0,000)^{*}$ \\
\hline GDP & 0,0120 & 0,00457 & $2,64(0,008)^{*}$ \\
\hline BVFO & $-0,0224$ & 0,01093 & $-2,05(0,040)^{* *}$ \\
\hline DPRI & $-0,4292$ & 0,12047 & $-3,56(0,000)^{*}$ \\
\hline Gözlem Sayısı & 1172 & Yatay Kesit Sayısı & 23 \\
\hline F istatistiği & 24,69 & Olasılık Değeri & 0,0000 \\
\hline Frup-test & 13,95 & Olasilık Değeri & 0,0000 \\
\hline R2 (Grup içi) & 0,1314 & corr(u_i, Xb) & $-0,3391$ \\
\hline R2 (Gruplar arası) & 0,0001 & sigma_u & 0,9638 \\
\hline R2 (Genel) & 0,0603 & sigma_e & 1,4796 \\
\hline & & rho & 0,2979 \\
\hline
\end{tabular}

Not: Prob. $<0,01$ ise *, 0,01 $\leq$ Prob. $<0,05$ ise **, 0,05 $\leq$ Prob. $\leq 0,10$ ise ***. Parantez içindeki değerler olasllkk değerlerini göstermektedir.

Modelin F istatistik değeri 24,69 olup olasılık değeri ise 0,05 'ten küçüktür. Dolayısıyla modelin genel olarak anlamlılığını ifade eden alternatif $\mathrm{H} 1$ hipotezi kabul edilmektedir. Veri setinde, birimler arasında farklılığın olmadığını ifade eden boş hipotez için $\mathrm{F}$ grup istatistiğinin değeri 13,95'tir. Bu istatistiğin, 0,05 önem düzeyine göre anlamlı olduğu görülmüştür. Diğer bir ifadeyle, aktif kârlılığın belirleyenleri açısından değiş̧kenler arasında farklılık mevcuttur. Modelin değişkenlerinin yorumu şu şekildedir: 
Ay Yalçınkaya, A.E. \& S. Şanlısoy \& Ü. Aydın (2016), "Türk Bankacılık Endüstrisinde

Performansın Belirleyenleri ve Politik İstikrarsızlık İlişkisi”, Sosyoekonomi, Vol. 24(27), 161-182.

- TCMB borç verme faiz oranı (BVFO), likidite sıkışıklığına düşen bir bankanın, Merkez Bankasından kısa vadeli borçlanmak için ödemeyi kabul ettiği faiz oranıdır. Faiz koridorunun üst bandını oluşturmakta olup bankanın maliyetlerinde bir artış yaratacağından banka performansıyla arasında negatif bir ilişki beklenmektedir. Uygulama sonucu, beklentilerle uyumlu olup TCMB borç verme faiz oranını (BVFO) yüzde 1 arttırdığında banka performansının temel göstergelerinden biri olan aktif kârlılığı yüzde 0,02 oranında düşürmektedir.

- $\quad$ GSYİH büyüme oranı (GDP) bir ekonomideki toplam iktisadi faaliyetlerdeki değişimi göstermesi bakımından en yaygın kullanılan makroekonomik değişkendir. Büyüme oranının, kredilerin arz ve talebine etki ettiği düşünülmekte ve banka performansıyla arasında pozitif bir ilişki beklenmektedir. Sonuç beklentilerle uyumlu olup GSYİH büyüme oranında (GDP) meydana gelen yüzde 1'lik artış bankaların aktif kârlılığını yüzde 0,01 oranında arttırmaktadır.

- Kur Oynaklığ (DKUROYN): Türkiye'deki bankaların yabancı para cinsinden gerek yükümlülükleri gerekse varlıkları ağırlıklı Dolar ve Euro bazlıdır. Uygulama sonucuna göre iki para biriminin eşit ağırlığına göre oluşturulan kur oynaklığında meydana gelen yüzde 1'lik artış bankaların aktif kârlılığı üzerinde TCMB borç verme faiz oranı ve GDP büyüme oranından çok daha güçlü bir etki yaratmaktadır (-1,6674). Ancak etkinin yönü negatiftir. 2001 sonrası başta FED olmak üzere diğer merkez bankaların yarattığı parasal genişleme dolayısıyla Türkiye'deki bankalar yurtdışı piyasalardan ABD Doları ve Euro bazında borçlanarak yurtiçi piyasalarda TL bazında kredi verme yoluna gitmişlerdir. Ancak 2013 yılı sonrası FED’in ve Avrupa Merkez Bankası'nın izlediği politikalar ile iç siyasi gelişmeler sonrası kurlarda meydana gelen artış yönündeki istikrarsızlık bankaların kur ve çapraz kur riskine girmesine neden olmuştur. Diğer yandan TL karşısında kurlarda meydana gelen artış bankaların döviz pozisyonlarını olumsuz etkilemiştir. $\mathrm{Bu}$ gelişmelerin doğal sonucu bankaların aktif kârlılığı negatif etkilenmektedir.

- Bankanın aktif büyüklüğü (LRTA), performansın önemli belirleyicilerinden biridir. Literatürden bilindiği üzere banka ölçeklerindeki farklılıklar, bankalara ölçek ekonomilerine dayanan avantajlar veya dezavantajlar getirebilir. Aktif büyüklüğü ile ilgili ampirik çalışmaların sonuçları çelişkilidir. Literatürde büyük bankaların ölçek ekonomisinden yararlandığını bulan çalışmalar mevcuttur. Çalışmamızın uygulama sonucu da bu paralellikte çıkmıştır. Buna göre bankaların aktif büyüklüğünde meydana gelen yüzde 1'lik artış aktif kârlılığı yüzde 0,2 arttırmaktadır. Büyük ölçekli bankalar yukarıda da değinildiği gibi birçok ölçek avantajı sağlayabilmektedir.

- Sermaye yeterliliği rasyosu (SY), bankanın yaşayabileceği şokların üstesinden gelmesi için yeterli olan özkaynak miktarını gösterir. Literatürden elde edilen 
Ay Yalçınkaya, A.E. \& S. Şanlısoy \& Ü. Aydın (2016), “Türk Bankacılık Endüstrisinde

Performansın Belirleyenleri ve Politik İstikrarsızlık İlişkisi”, Sosyoekonomi, Vol. 24(27), 161-182.

sonuçlar; bankaların kârlılık performanslarında kalıcılığı sağlamak için güçlü bir sermaye yapısının şart olduğunu göstermektedir. Çalışmamızda sermaye yeterliliği rasyosunun (SY) katsayısı 0,0422 olarak çıkmıştır. Literatüre uygun olarak etkinin yönü pozitif çıkmıştır. Bu oranın pozitif olması, bankanın dış kaynaklara olan bağımlılığını azaltması ve yüksek kârlara ulaşmasına yardımcı olmaktadır. Özkaynaklar, bankaların ekonomik bir değer oluşturması yönünde bir güvence oluşturmaktadır. Bu nedenle, yeterli bir özkaynak düzeyine sahip bankaların yetkinliği artabilecektir. Ekonomik karar birimleri bu tip bankalara daha fazla güven duyarak mevduat ve kredi taleplerini bu bankalara yönlendireceklerdir. Ancak, bankaların, düşük risk ağırlıklı varlıklar ve buna karşılık yüksek özkaynak bulundurması dolayısıyla SY'nin çok yüksek olması finansmanda kullanılan klasik daha fazla risk, daha fazla getiri teorisiyle çelişmesine neden olmakta ve performansın düşmesine yol açabilecektir. Böylesi bir durumda, bankaların ahlaki tehlike ve ters seçim riskini azaltmak için üretimini kıstığını söyleyebilmek mümkündür. Çalışmamızda etkinin yönünün pozitif olduğu dikkate alınırsa SY'deki artışın aktif kârlılığı olumlu etkilediği, diğer yandan SY'nin yukarıda değinilen olumsuz etkileri nedeniyle de olumluluğun gücünü zayıflattığı söylenebilir.

- Mevduatlar krediye dönüştürüldüğü sürece net faiz marjı ve kârlılık daha da yükseleceği beklentisi nedeniyle toplam krediler/toplam aktifler (TKTA) değişkenin işaretinin pozitif çıkması olasıdır. Bu beklentiye uygun olarak toplam krediler/toplam aktiflerde (TKTA) meydana gelen yüzde 1'lik artış aktif kârlılıkta yüzde 0,04'lik artış yaratmaktadır. İlişkinin gücünün zayıf olması bankaların toplam kredi/toplam aktif oranını arttırırken daha çok risk almasından kaynaklanıyor olabilmektedir.

- Politik istikrarsızlıktaki (DPRI) artış, ülkenin mikro ve makro ekonomik ve finansal karar ve davranışları olumsuz yönde etkilediği gözlemlenmektedir. $\mathrm{Bu}$ nedenle bu değişkenin banka performansı üzerindeki etkisinin negatif olması beklenmektedir. Nitekim politik risk ve istikrarsızlıktaki yüzde 1'lik artış bankaların aktif kârlılığını yüzde 0,4 oranında düşürmektedir.

Modelde $\varepsilon$ hata terimini c sabiti sembolize etmektedir. Sabit terimin yüksek ve negatif olması $(-6,3572)$ modele dâhil ettiğimiz içsel (mikro) ve dışsal (makro) değişkenler tarafından açıklanamayan yapısal faktörlerin bankaların kârlılığı üzerinde etkisinin yüksek ve negatif olduğunu göstermektedir. Ek 1'de yer alan modelden politik istikrarsızlık (DPRI) değişkeni çıkarılarak uygulama yapılmış ve sonuçlar yeniden üretilmiştir. Söz konusu bu modelin sabit terimi $-5,5928$ birimdir. Politik istikrarsızlık içeren yukarıdaki modelin sabit terimi Ek 1'deki modelin sabit terimine göre 0,76 birim küçülmüştür. Buna göre politik istikrarsızlık değişkeninin bileşiminde yer alan yapısal faktörlerin bankaların kârlılığı üzerinde etkisinin olduğu bu analiz ile ortaya çıkmaktadır. Diğer yandan modele dâhil edilen değişkenler dışında bankaların kârlılığını etkileyen ve literatürde yer alan birçok değişken modele dâhil edilerek uygulama yapılmıştır. Ancak değişkenler, sapmalı ve tutarsız sonuçlar ürettiğinden modelden çıkarılmıştır. Çalışmamızın sınırlarını aşan diğer yapısal ve içsel 
Ay Yalçınkaya, A.E. \& S. Şanlısoy \& Ü. Aydın (2016), “Türk Bankacılık Endüstrisinde

Performansın Belirleyenleri ve Politik İstikrarsızlık İlişkisi”, Sosyoekonomi, Vol. 24(27), 161-182.

faktörlerin banka performansı üzerindeki etkilerinin analiz edilmesi ve tartışılması bir başka çalışmanın konusunu oluşturması açısından önemli görülmektedir.

\section{Sonuç}

Ekonomik gelişmenin önemli kurumlarından biri olan bankacılık endüstrisinin performansı ve finansal istikrarı, ekonominin içindeki her bir karar birimi açısından önemlidir. Bankacılık endüstrisinin istikrarı ve performansı; gerek bankaya özgü mikro (içsel) değişkenlerden, gerekse bankanın kontrol edemediği makro (dışsal) değişkenlerden etkilenmektedir. Dışsal değişkenlerin başında da politik istikrarsızlık gelmektedir. Politik istikrarsızlık, ekonomik birimlerin beklentileri üzerinden gerek makro, gerek mezo ve gerekse mikro ekonomik alanlarda etkili olmaktadır. Bu bağlamda, bu çalışmada Türkiye'de sıklıkla yaşanan politik istikrarsızlığın diğer içsel ve dışsal değişkenlerle birlikte Türk bankacılık endüstrisinin performansı üzerindeki etkileri ortaya konulmaya çalışılmaktadır. Böylece ele alınan değişkenlerin, bankacılık üzerine etkileri incelenerek bankacılık endüstrisinin daha etkin çalışabilmesinin koşulları belirlenmektedir. Dolayısıyla daha etkin çalışacak finansal kesim, reel kesimin de etkinliğini sağlayarak ülke ekonomisinin büyümesi üzerinde pozitif bir etki yaratacaktır. Bunun yanı sıra, makroekonomik ve politik gelişmelerin banka performansına yaptığı etki siyasal karar alıcılara uyguladıkları politikanın endüstri üzerindeki etkisine dikkat çekilecek, banka yöneticilerine ise yönetim performansları hakkında yol gösterici olacaktır.

Bu kapsamda, Türkiye'de faaliyet gösteren 23 ticari bankanın performans1 $2002 q 4$-2015q2 dönem aralığ1 için analiz edilmektedir. Panel veri analizi yönteminin uygulandığı çalışmada, bankacılık endüstrisinin performans ölçütü olarak aktif kârlılığı kullanılmaktadır.

Analiz sonuçları genel olarak yorumlandığında, bankalarda ölçek ekonomisinden uzaklaşmanın performansı olumsuz yönde etkilediği, sermaye yeterlilik oranının performansa etkisinin pozitif olduğu, diğer yandan risklerin performansa negatif yönde etki ettiği görülmektedir. Çalışmanın bir diğer sonucu ise, kurlarda ve TCMB borç verme faiz oranında meydana gelen artışın, gerek yabancı para birimi cinsinden borçların maliyetini gerekse fonların maliyetini arttırması açısından bankaların performansını olumsuz etkilemesidir. $\mathrm{Bu}$ açıdan bakıldığında, değişen ekonomi koşullarında, bankaların fon çeşitliliğine gitmeleri ve döviz pozisyonlarını dengelemeleri önem arz etmektedir.

Önemli dışsal değişkenlerden biri olan politik istikrarsızlık ülkedeki politik belirsizlikleri artırmakta bu da politik riski yükseltmektedir. Politik istikrasızlığın sıklıkla yaşandığı Türkiye'de bankaların da bu istikrarsızlıktan olumsuz etkilendiği, çalışmanın önemli bulgularından biridir. Bu değişkenin özellikle faiz ve kredi kanalı üzerinden makro etkiler ve sermaye yapısı çok güçlü olmayan bankalar üzerinden finansal risk ve kırılganlığı arttırarak mikro etkiler yaratması olasıdır. Bu riske karşı bankaların sermaye yapılarını güçlü tutmayı sürdürmeleri, geleneksel bankacılık faaliyetlerinin yanında alternatif kazanç koşulları ve alternatif hizmetler bulması ve uluslararası fon çeşitlendirmesi ile sistematik 
riskleri azaltması bankacılık sisteminin performansının geliştirilmesinde önemli rol oynayacaktır.

Çalışmanın sonuçları bütün olarak incelendiğinde, banka performansını açıklamada mikroekonomik değişkenlerin yanı sıra makroekonomik değişkenlerin de etkili olduğunu belirtmek mümkündür. Bankaların performanslarının kendi aktif kalitelerine, maliyetlerini kontrol etmelerine, özkaynak kalitesine, verdikleri kredi miktarına bağlı olmasının yanında makro ve küresel ekonomik ve politik gelişmeleri dikkate almak zorunda oldukları sonucuna ulaşılmaktadır. Buna göre bankaların mikro düzeyde kendi bilanço kalemlerini izlemelerinin yanı sıra ulusal ve küresel düzeyde ekonomik ve politik gelişmeleri dikkate almaları, izlemeleri ve faaliyetlerini denetleyecek mekanizmalar ile bu sektörün sağlığını belirlemede önemli rol oynayacaktır.

\section{Kaynaklar}

Abreau, M. \& M. Mendes (2002), "Commercial Bank Interest Margins and Profitability: Evidence from EU Countries”, University of Porto Working Paper Series.

Alesina, A. \& R. Perotti (1996), "Income Distribution, Political Instability, and Investment”, European Economic Review, 40, 1203-1228.

Athanasoglou, P.P. \& S.N. Brissimis \& M.D. Delis (2008), "Bank-Specific, Industry-Specific and Macroeconomic Determinants of Bank Profitability", Journal of International Financial Markets, Institutions \& Money, 18: 121-136.

Ayaydın, H. \& İ. Karaaslan (2015), "Politik Belirsizlikler ve Finansal Performans: BIST Örneği”, Gümüşhane Üniversitesi Sosyal Bilimler Enstitüsü Elektronik Dergisi, 6, 51-63.

Aydın, Ü. (2010), “Türk Finans Endüstrisinde Karşılaştırmalı Organizasyonel Etkinlik: Türkiye Örneği”, Dokuz Eylül Üniversitesi Sosyal Bilimler Enstitüsü Yayınlanmamış Doktora Tezi, İzmir.

Aydın, Ü. \& R. Kök (2013), “Türk Bankacılık Sektöründe Organizasyonel Etkinlik ve Etkinsizliğin Kaynakları", Verimlilik Dergisi, 2, 7-38.

Baltagi, B. (2005), Econometric Analysis of Panel Data, 3. Bask1, İngiltere: John Wiley \& Sons Ltd. Bankacılık Denetleme ve Düzenleme Kurumu (2015), Türk Bankacılık Sektörü Temel Göstergeleri Haziran 2015, <https://www.bddk.org.tr/WebSitesi/turkce/Raporlar/TBSGG/14382tbs_temel_gostergel er_haziran_2015.pdf>, 28.11.2015.

Bashir, A.H. (2000), “Assesing the Performance of Islamic Banks: Some Evidence from Middle East”, Jordan 8. ERF Meetings Working Paper.

Boyd, J.H. \& D.E. Runkle (1993), "Size and Performance of Banking Firms: Testing the Predictions of Theory", Journal of Monetary Economics, 31, 47-67.

Çingi, S. \& A. Tarım (2000), “Türk Banka Sisteminde Performans Ölçümü: DEA-Malmquist TFP Endeksi Uygulaması”, Türkiye Bankalar Birliği Araştırma Tebliğleri Serisi 1.

Demirgüç-Kunt, A. \& H. Huizinga (1999), "Determinants of Commercial Bank Interest Margins and Profitability: Some International Evidence", The World Bank Economic Review, 13, 379408. 
Doğru, C. (2011), "Kârlılığın Belirleyicileri Analizi: Teori ve Orta Ölçekli Bir Banka Uygulaması”, Maliye Finans Yazılarl, 91, 47-75.

Eken, H.M. (1997), “Banka Performansı Ölçümüne Risk ve Kârlılık Yaklaşımı: Türkiye’de Faal Ticari Bankalar Örneği”, IMMKB Dergisi, 8 (29), 17-41.

Eren, E. \& M. Bildirici (2001), “Türkiye'de Siyasal ve İktisadi İstikrarsızlık: 1980 - 2001”, İktisat İşletme ve Finans, 16 (187), 27-33.

Frantzen, D. (2002), "Intersectoral and International R\&D Knowledge Spillovers and Total Factor Productivity", Scottish Journal of Political Economy, 49 (3), 280-303.

Gerlach, S. \& W. Peng \& C. Shu (2015), Bank for International Settlements Papers, 22. <www.bis.org/publ/bppdf/bispap22x.pdf>, 28.10.2015.

Greene, W.H. (2003), Econometric Analysis, 5. Bask1, Prentice Hall International, New Jersey.

Guru, B. \& J. Staunton \& B. Balashanmugam (2002), "Determinants of Commercial Bank Profitability in Malaysia," University Multimedia Working Papers.

Hausman, J.A. (1978), "Specification Tests in Econometrics", Econometrica, 46(6), 1251-1271.

Ho, T.S. \& A. Saunders (1981), "The Determinants of Bank Interest Margins: Theory and Empirical Evidence", Journal of Financial \& Quantitative Analysis, 16, 581-600.

Jiang, G. \& N. Tang \& E. Law \& A. Sze (2003), "Determinants of Bank Profitability in Hong Kong", Hong Kong Monetary Authority Research Memorandum, <http://www.info.gov.hk/hkma/eng/research/RM_on_Banz_Profitability.pdf〉, 06.12.2015.

Kolb, R.W. \& R.J. Rodriguez (1996), Financial Institutions, Cambridge-Massachusetts, Blackwell Publishers.

Lartey, V.C. \& S. Antwi \& E.K. Boadi (2013), "The Relationship between Liquidity and Profitability of Listed Banks in Ghana", International Journal of Business and Social Science, 4(3), 48-56.

Maddala, G.S. (1999), "On the Use of Panel Data Methods with Cross-Country Data”, Annales D'Economie et de Statistique, 55/56, 429 - 449.

Naceur, B.S. (2003), "The Determinants of the Tunisian Banking Industry: Panel Evidence", Proceedings of the Economic Research Forum 10th Annual Conference, Marakesh, Morocca.

Naceur, S.B. \& M. Goaied (2001), "The Determinants of the Tunisian Deposit Banks' Performance", Applied Financial Economics, 11, 317-319.

Pasiouras, F. \& K. Kosmidou (2007), "Factors Influencing the Profitability of Domestic and Foreign Commercial Banks in the European Union”, Research in International Business and Finance, 21, 222-237.

Taşkın, F.D. (2011), “Türkiye'de Ticari Bankaların Performansını Etkileyen Faktörler“, Ege Akademik Bakış, 11(2), 289-298.

Tunay, K.B. \& A.M. Silpar (2006b), "Türk Ticari Bankacılık Sektöründe Kârlılığa Dayalı Performans Analizi-II”, Türkiye Bankalar Birliği Araştırma Tebliğleri Serisi, 2006/II.

Tunay, K.B. \& A.M. Silpar (2006a), "Türk Ticari Bankacılık Sektöründe Kârlılığa Dayalı Performans Analizi-I”, Türkiye Bankalar Birliği Araştırma Tebliğleri Serisi, 2006/I.

Türker-Kaya, Y. (2001), “Türk Bankacılık Sisteminde Net Faiz Marjının Modellenmesi”, Bankacılık Düzenleme ve Denetleme Kurumu Mali Sektör Politikaları Dairesi Çalışma Raporlarl, 2001/4. 
Türker-Kaya, Y. (2002), “Türk Bankacılık Sektöründe Kârlılığın Belirleyicileri 1997-2000”, Bankacılık Düzenleme ve Denetleme Kurumu Mali Sektör Politikaları Dairesi Çalışma Raporlarl, 2002/1.

Türkiye Bankalar Birliği (2008), 50. Yılında Türkiye Bankalar Birliği ve Tükiye'de Bankacılık Sistemi 1958-2007, <https://www.tbb.org.tr/Content/Upload/Dokuman/808/2tbb50yil.pdf>, 28.11.2015.

Wu, H.L. \& C.H. Chen \& F.Y. Shiu (2007), "The Impact of Financial Development and Bank Characteristics on the Operational Performance of Commercial Banks in the Chinese Transitional Economy", Journal of Economic Studies, 34, 401-414.

Yıldız, S. (2010), "İşletme Performansının Ölçümü Üzerine Bankacılık Sektöründe Bir Araştırma”, Erciyes Üniversitesi İktisadi ve İdari Bilimler Fakültesi Dergisi, Sayı: 36, 179-193.

\section{EK: 1}

\section{Panel Sabit Etkiler Modeli (2): DPRI Değişkeni Olmadan}

\begin{tabular}{|l|r|lr|r|}
\hline \multicolumn{1}{|c|}{ Bağımlı Değişken: ROA } & \multicolumn{1}{c|}{ Katsayı } & \multicolumn{1}{c|}{ Standart Hata } & \multicolumn{1}{c|}{ t Değeri } \\
\hline Sabit & $-5,5928$ & & 1,1963 & $-4,67(0,000)$ \\
\hline SY & 0,0456 & 0,0046 & $9,79(0,000)$ \\
\hline TKTA & 0,0397 & 0,0045 & $8,78(0,000)$ \\
\hline LRTA & 0,1989 & & 0,0719 & $2,77(0,006)$ \\
\hline DKUROYN & $-1,2280$ & 0,3432 & $-3,58(0,000)$ \\
\hline GDP & 0,0137 & & 0,0045 & $3,00(0,003)$ \\
\hline BVFO & $-0,0318$ & & 0,0089 & $-3,58(0,000)$ \\
\hline Gözlem Sayısı & 1172 & Yatay Kesit Sayısı & 23 \\
\hline F istatistiği & 149,01 & Olasılık Dĕgeri & 0,000 \\
\hline R2 (Grup içi) & 0,1197 & corr(u_i, Xb) & 0 \\
\hline R2 (Gruplar arası) & 0,0027 & sigma_u & 0,6577 \\
\hline R2 (Genel) & 0,0723 & sigma_e & 1,4871 \\
\hline & & rho & 0,16362 \\
\hline
\end{tabular}

